\title{
Names in Brief
}

\section{More California Notes.-}

The derivation of California (Names, June, 1954) from the use in Montalvo's novel still does not rule out the possibility of an influence from Greek. Although we may safely leave Davidson's "bird" for the second part perched in the trees, the stem, kal, Kalli, Kalo was so familiar to anyone with even a rudimentary knowledge of Greek, or none at all, that Montalvo may well have picked it with that in mind. Callifolis (a name known to Shakespeare of little Greek, though he borrowed it from an old flag) and Caligrafia were forms which I presume (without any evidence) that Montalvo knew. Lewis Carroll in Jabberwocky writes "O frabjus day, Callooh, Callay"-nonsense syllables which yet suggest the idea of pretty, fine, good, generally O.K., which the word regularly had in Greek, e.g. in the names on the Greek vases. There is, of course, a British schoolboy influence in 19th century England which was not there in 16th century. I suppose we must write Montalvo's ghost for a final answer and ask him whether he associates warm or pretty with the sound Kali. His answer might be "both."

Donald G. BAKER

Epistemological and cultural considerations seem to throw light on-if not satisfactorily explain-the origin of the name California. (Names, June, 1954.) When this name was created, patterns of Arab traditional literary illusions were strong influences in Spain. What may be more significant, "immediate apprehension" methods of knowing (naming) were still widely disbursed, as were related methods of knowing by "primitive credulity," whence the persistence of superstitious beliefs in Western cultures of the period. The modern relative, systematic, or scientific methods of knowing by no means predominated Western mental habits. In Arab stories, sagas and literature, the Caliph had for centuries connoted more than a ruler. He was a symbol (of wealth, jewels, luxurious living, and command of beautiful and voluptuous women) having the 
power to convert any cobbler, dervish, camelteer, etc., into a facsimile of himself overnight and forever after. Califia certainly appears derived from Caliph by relative processes. In Arab traditions black women often represent the most voluptuous. The same processes explain the choice of a form of Caliph as a name for a fabulous land with a black queen, where anyone might become like a Caliph overnight - a land with the power to make everyone enjoy such opulence and luxuriousness at once and thereafter. The last syllables may be satisfactorily explained by "immediate apprehensive" methods of naming, identifying the mythical land, not by reference to any other land, but by particular pleasing sounds to its own particularity.

The explanation by Hale and conclusion by Gudde appear to have cultural validity, which conforms to, rather than violates etymological evidence and principles. To my own mind the cultural validity warrants hazarding the explanation by Hale-concurred in by Gudde as most sound-is correct and not apt to be modified in any fundamental manner.

Charles Edgar Gilliam

Street Names in Waverly.-Waverly in Lancaster County, Nebraska, was named in honor of Sir Walter Scott's historical novel Waverley, with a slight change in spelling. Naming the six avenues, which run east and west, for other novels in the Waverley series seems appropriate. They are Ivanhoe, Rob Roy, Kenilworth, Claverhouse, Durward, and Mannering. The more practical minded settlers must have named the six streets, which run north and south, for trees. They are Ash, Elm, Mulberry, Larch, Cottonwood, and Poplar. These names may have been the result of wishful thinking, for trees were scarce and highly valued for building houses and fences, and for fuel in the Great Plains region. There are now a good many maple trees in Waverly, though elms are the most numerous.

Richard NeOL

Soyuzivka is the name given by the Ukrainian National Association of America to their new home for the aged and an all-yearround resort near Kernhonkson, N.Y. The name does not exist in Ukraine; it is an American neologism created especially for nam- 
ing the place. The primary meaning of -ivka place names is "possession," "estate," "village," etc., of the person indicated in the root, as Bohdanivka, "estate of Bohdan." Since the stem soyuz means "association" the new name is the Ukrainian equivalent of "Home of the Association."

Amt-Eric.-The United Press recently supplied its subscribers with a news item based on the research of $\mathrm{H}$. A. Anderson of Wisconsin. According to this historian the root amt means "land of" in Scandinavian, and since Leif, the son of Eric first discovered the new continent the name America is simply a corruption of Amt-Eric, "land of Eric." Unless Moscow has already advanced its claim to the discovery and naming of America, it will only be a matter of time until a Russian scholar will find two roots in the Russian language which will supply the origin of the name America.

$$
\diamond \diamond \diamond
$$

Place Names on Ocracoke Island is the title of an excellent local study on place names by our member, C. A. Weslager, published in the North Carolina Historical Review, January 1954. Ocracoke Island is a twelve-mile ribbon of sand between Pamlico Sound and the Atlantic Ocean. Its fishing community on the southwest end of the island is one of the most primitive in the United States: some 5oo Robinson Crusoes, who as late as 1949 had no doctor, dentist, undertaker, jail, police officers, paved streets, local government. It stands to reason that in such a community place naming developed in a very primitive, all the more fascinating manner. Friend Weslager deserves a vote of thanks for having recorded these old names before (as he himself fears) they will be replaced by more conventional names with the advance of civilization. 